\title{
Evaluation of phospholipase activity of Candida albicans and its correlation with pathogenicity in mice
}

\author{
R. J. KOTHAVADE and M. H. PANTHAKI* \\ Division of Mycology, Department of Dermatology, Sir J. J. Group of Hospitals and Grant Medical College, \\ Bombay 400008 and *Department of Pathology, Sir H. N. Hospital, Bombay 400 004, India
}

\begin{abstract}
Sixty-one isolates of Candida albicans were tested for their phospholipase activity and this parameter was correlated with pathogenicity in albino mice. Of the isolates tested, $57(93 \%)$ showed appreciable phospholipase activity and of these, $55(90 \%)$ were pathogenic to mice. A significant correlation was found between phospholipase activity and involvement of kidneys in animal pathogenicity studies. The isolates of $C$. albicans, that exhibited higher phospholipase activity were found to be pathogenic for mice.
\end{abstract}

\section{Introduction}

The dimorphic fungus Candida albicans is an opportunist pathogen capable of causing superficial as well as systemic infections. Its ability to produce phospholipase is considered to be an important pathogenic feature [1]. It has been reported that the ability of $C$. albicans to produce cytolytic enzymes such as proteinase [2, 3] and phospholipases [4, 5] may be associated with pathogenicity of this dimorphic fungus. Phospholipase activity of $C$. albicans was first detected by growing the fungus on media supplemented with egg yolk [6,7] and lecithin [8]. Previous studies have shown $30-70 \%$ of $C$. albicans isolates to be phospholipase positive with varying degrees of phospholipase activity $[9,10]$. Samaranayake et al. showed that the secreted phospholipase activity of $C$. albicans can be a potential determinent of virulence [10]. Hence the present investigation examined the phospholipase activity of 61 clinical isolates of C. albicans with Sabouraud's dextrose agar supplemented with egg yolk, and correlated this parameter with pathogenicity in vivo in albino mice.

\section{Materials and methods}

Sixty-one isolates of $C$. albicans were obtained from patients who were attending the dermatology clinic of Sir J. J. Group of hospitals and Grant Medical

Received 20 Aug. 1996; revised version accepted 28 May 1997.

Corresponding author: Dr R. J. Kothavade.
College, Bombay-8, during the period MarchNovember 1995.

Skin scrapings were taken from infected parts of the body, e.g., nail fold (paronychia), glans of penis (candidal balanitis in diabetic patients), peri-anal area (perianal candidosis), groin (inguinal candidiosis), interdigital spaces (interdigital candidosis) and oral cavity (oral thrush/oral candidosis). Skin scrapings, subjected to a $\mathrm{KOH} 10 \%$ wet mount, were cultured on Sabouraud's dextrose agar (SDA) supplemented with chloramphenicol and incubated at room temperature for 7 days. Colonies on SDA were identified by standard methods [11], i.e., the germ tube test, ability to form chlamydospores on cornmeal agar and sugar fermentation and assimilation tests.

Of the 61 clinical isolates of $C$. albicans, the greatest number, $19(31 \%)$, were from the oral cavity, and the least came from groin and interdigital spaces - 5 $(8 \%)$ each.

\section{Phospholipase activity}

Phospholipase activity was determined by the method of Price et al. [9]. An 18-h culture of each isolate on SDA was harvested in $5 \mathrm{ml}$ of sterile saline and the yeast numbers were then adjusted to yield a suspension of $10^{6}$ organisms $/ \mathrm{ml}$ by haemocytometric counts. This suspension $(10 \mu \mathrm{l})$ was spot inoculated on to SDA plates supplemented with egg yolk $(8 \% \mathrm{w} / \mathrm{v})$ and mineral salts $(0.05 \mathrm{M}$ calcium chloride and $1 \mathrm{M} \mathrm{NaCl})$. After incubation of the inoculated plates at $37^{\circ} \mathrm{C}$ for up to 4 days in a humid chamber, the diameter of the resultant colonies and that of the precipitation zone 
around them were measured with a measuring scale. The experiment was performed in triplicate. Phospholipase activity ( $\mathrm{Pz}$ value) was calculated as the ratio of the diameter of the colony to the diameter of the colony plus that of the precipitation zone [9].

\section{Animal pathogenicity}

Swiss albino mice weighing $18-20 \mathrm{~g}$ were used (Haffkine Research Institute, Parel, Bombay 400012, India). A suspension of $5 \times 10^{3}$ yeast cells $/ \mathrm{ml}$ was prepared for inoculation with a Levy haemocytometer chamber slide (Weber). Two sets of six mice were used for each isolate of $C$. albicans. Each of the six mice was inoculated intravenously via the tail vein with $1 \mathrm{ml}$ of a $C$. albicans suspension prepared as above. Control mice were inoculated with $1 \mathrm{ml}$ of yeast-free saline. After 15 days, the mice were killed, dissected and inspected for macroscopic lesions of the kidneys. Both kidneys of each mouse were weighed. Small portions of infected kidneys were crushed between two slides and smears were stained by Gram's method and examined microscopically for yeast and hyphal elements. Both kidneys were also cut into two equal parts - half of the infected organ was put into sterile normal saline for culture and the remainder into formalin $10 \%$ solution for histopathological studies with the periodic acidSchiff (PAS) staining method.

\section{Results}

Of the 61 clinical isolates of C. albicans, 25 (41\%) showed $\mathrm{Pz}$ values of $0.40-0.45$ (Table 1).

Three oral isolates, two from nail-fold and two from interdigital spaces showed the highest phospholipase activity $(\mathrm{Pz}=0.35-0.40)$ and also induced lesions in both kidneys in all 42 mice inoculated with these strains $(r=0.90)$. A total of 25 isolates exhibited $\mathrm{Pz}$ values of $0.40-0.45$ and also elicited lesions in both kidneys of the 150 mice inoculated with these strains $(\mathrm{r}=0.83)$ (Table 1, Fig. 1).

A total of 23 isolates with $\mathrm{Pz}$ values of $0.45-0.60$ elicited unilateral right kidney infection in all 138 mice inoculated $(r=0.82)$ while the remaining six isolates with $\mathrm{Pz}$ values $>0.65$ failed to infect the kidneys of any of the 36 test animals (Table 1, Fig. 1).

The results of this study indicate that the strains of $C$. albicans with the highest phospholipase activity showed appreciable involvement of both the kidneys in experimental infections. However, the strains with lower phospholipase activity showed unilateral involvement of right kidneys. Overall, the correlation between these two parameters was high $(r=0.85)$. The isolates with low phospholipase activity (in the range $0.65-0.80$ ) and negative strains $(\mathrm{Pz}=95-100)$ failed to show any infection in either kidney.

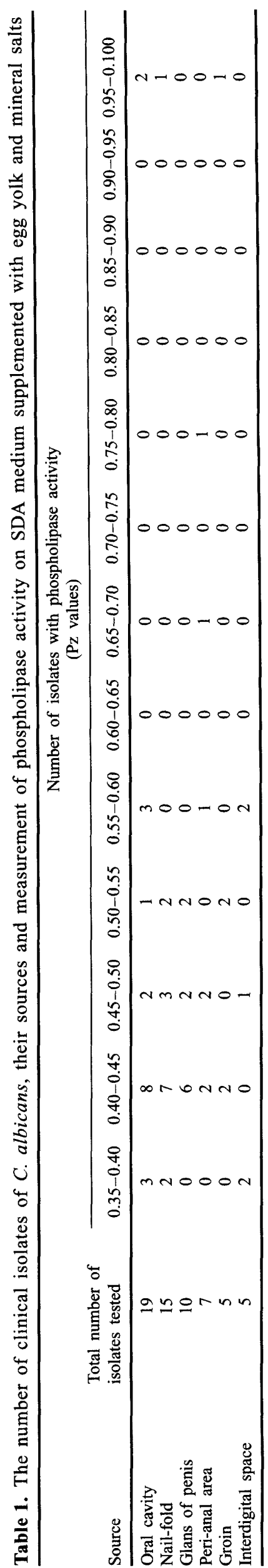




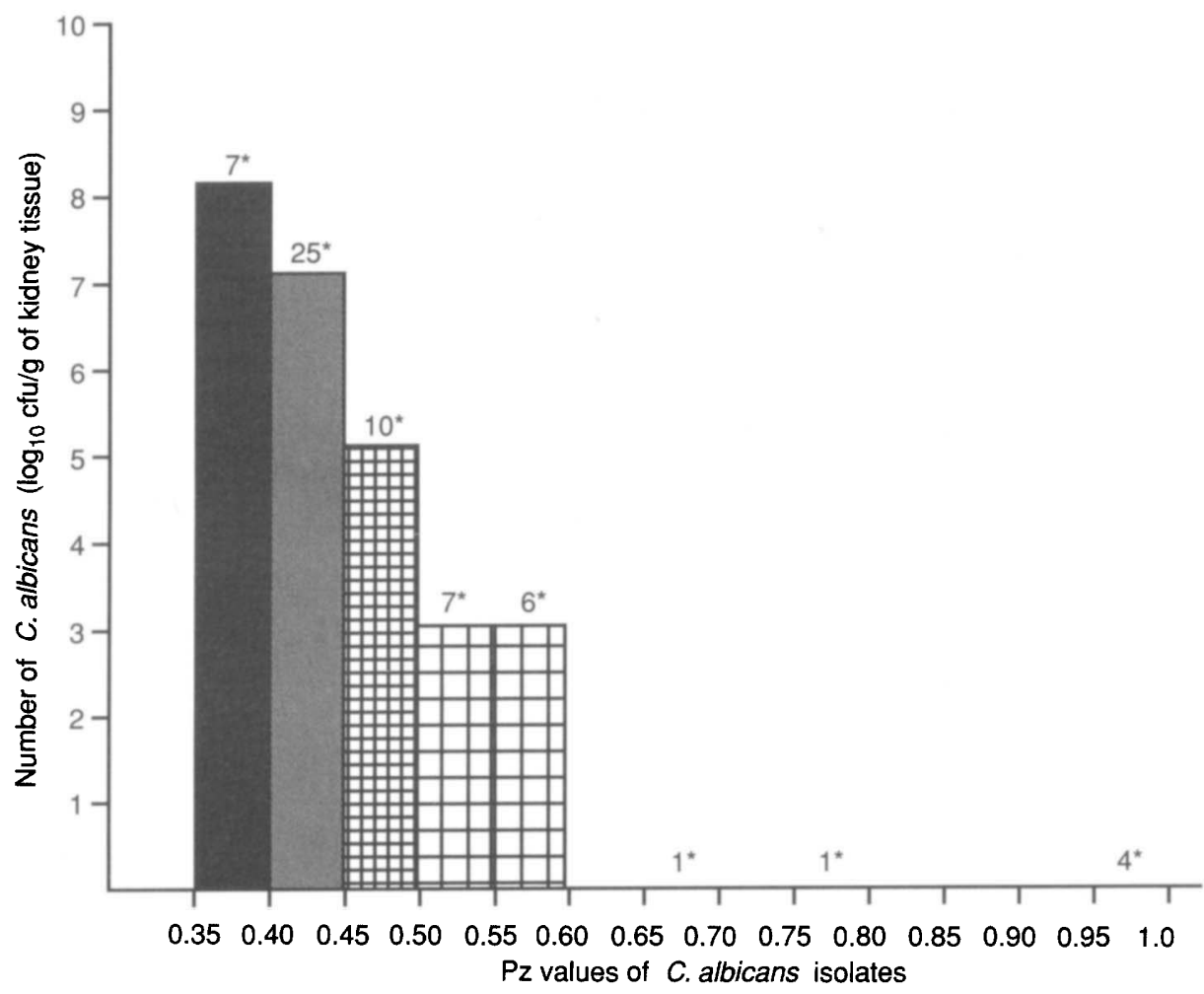

Fig. 1. C. albicans (cfu) recovered from kidneys of mice inoculated with phospholipase positive and negative isolates $\left(5 \times 10^{3}\right.$ yeast cell $\left./ \mathrm{ml}\right) ; \quad$ and $\mathbf{D i l a t e r a l}$ involvement of kidneys; 1 and $\Theta$ unilateral involvement of kidneys. *Number of isolates.

\section{Discussion}

These results suggest that clinical isolates of $C$. albicans exhibit varying degrees of phospholipase activity and are consistent with previous observations by Samaranayake et al. [10]. The percentage of phospholipase-negative $C$. albicans isolates in the present study was very low $(6.55 \%)$ compared with previous studies, which demonstrated that $23 \%$ (6 of 28 ) of oral isolates, $10.45 \%$ ( 5 of 28 ) of blood isolates, $50 \%$ (14 of 28 ) of wound isolates and $70 \%$ (9 of 13) of urine isolates were phospholipase-negative [9]. The phospholipase-negative isolates in the present study were obtained from the oral cavity $(2 ; 10 \%)$, from the nail fold $(1 ; 1.64 \%)$ and from the peri-anal area $(1$; $1.64 \%)$.

The rationale behind selecting the kidneys for evaluating the pathogenicity of $C$. albicans was that when isolates of $C$. albicans are injected via the tail vein, the kidneys are more severely infected than any other organ $[12,13]$. As a result, the kidneys have been used commonly for monitoring pathogenicity of C. albicans in vivo [14].

With regard to the virulence of C. albicans, all 42 mice in the group that received phospholipase-positive yeast cells ( $\mathrm{Pz}$ values $0.35-0.45)$ showed macroscopic lesions (i.e., grey to white lesions) in both kidneys after 15 days. However, five of six isolates yielded more yeast cells (cfu) from left kidneys than from right kidneys. Although MacDonald and Odds [13] found no significant difference in cfu between right and left kidneys when the inoculum size was $1 \times 10^{6}$ yeast cells $/ \mathrm{ml} /$ mouse, Hurley and Winner [12] observed unilateral kidney involvement in experimental candidosis in mice, particularly with a low inoculum. As in the present study, Kwong-Chung and Tomm [14] also reported that the frequency of unilateral involvement of kidneys decreased with an increase in inoculum and the phenomenon of unilateral kidney enlargement or atrophy was also reported in mice that were inoculated with conidial suspensions of Aspergillus bisporus [15]. When the conidial suspension was injected via the tail vein, this atrophy or enlargement was three times more frequent in right kidneys. It is reported that right kidneys are slightly heavier and higher in position [16], and this was the case in the present study $(0.02 \mathrm{~g}$ versus $0.5 \mathrm{~g})$. Whether this weight difference was related to infection rate is a question which needs to be resolved.

\section{References}

1. Odds FC. Candida and candidiasis. Leicester, Leicester University Press. 1979.

2. Macdonald F, Odds FC. Inducible proteinase of Candida albicans in diagnostic serology and in the pathogenesis of systemic candidosis. $J$ Med Microbiol 1980; 13: 423-425.

3. Ruchel R, Tegeler R, Trost M. A comparison of secretory proteinases from different strains of Candida albicans. Sabouraudia 1982; 20: 233-244.

4. Costa AL, Costa AC, Misefari A, Amato A. Atti Sociata 
peloritana di scienze fische mathematische naturali 1968; XIV: $93-101$.

5. Louria DB, Brayton RG, Finkel G. Studies on the pathogenesis in experimental Candida albicans infections in mice. Sabouraudia $1963 ; 2$ : 271-283.

6. Costa AL, Misefari A, Amato A. Enzymatic activities of mycetes. I. Enzymatic activity of Candida albicans in egg yolk containing media. Atti XIV Congresso Nazionale di Microbiologia, Messina Taormina. 1969.

7. Werner H. [Studies on the lipase activity in yeasts and yeastlike fungi.] Untersuchungen uber die lipase-aktivitat bei hefen and hefeahnlichen pilzen. Zentralbl Bakteriol Orig 1966; 200: 113-124.

8. Costa AL, Missefari A, Amoto A. Enzymatic activities of mycetes. II. Phosphotidase activity in $C$. albicans in media containing lecithin. Atti XIV Congresso Nazionale di Microbiologia, Messina Taormina. 1969.

9. Price MF, Wilkinson ID, Gentry LO. Plate method for detection of phospholipase activity of Candida albicans.
Sabouraudia 1982; 20: 7-14.

10. Samaranayake LP, Raeside JM, MacFarlane TW. Factors affecting the phospholipase activity of Candida species in vitro. Sabouraudia 1984; 22: 201-207.

11. Lodder J. The yeasts: taxonomic study, 2nd edn. Amsterdam, Elsevier. 1984.

12. Hurley R, Winner HI. Experimental renal moniliasis in the mouse. J Pathol Bacteriol 1963; 86: 75-82.

13. Macdonald F, Odds FC. Virulence for mice of a proteinasesecreting strain of Candida albicans and proteinase-deficient mutant. $J$ Gen Microbiol 1983; 129: 431-438.

14. Kwon-Chung KJ, Tom WK. Unilateral involvement of kidneys in mice infected with Candida albicans. Sabouraudia 1985; 23: $81-83$

15. Kwon-Chung KJ, Fennell DI. A new pathogenic species of Aspergillus. Mycologia 1971; 63: 478-489.

16. Dunn TB. Renal disease of the mouse. In: Cotchin E, Roe FJC (eds) Pathology of laboratory rats and mice. Oxford, Blackwell Scientific Publications. 1967: 149-179. 